\title{
Household Welfare and Forest Dependence in Southern Malawi
}

\author{
Monica Fisher \\ Rural Poverty Research Center, Oregon State University, \\ 221 Ballard Hall, Corvallis, OR 97331; fisherm@oregonstate.edu
}

Abstract

This paper examines the role forests play in alleviating poverty in rural Malawi. Data from three villages in southern Malawi indicate high levels of forest dependence. Gini decomposition shows that access to forest income reduced measured income inequality at the study sites. Tobit analysis of the determinants of reliance on low-return and highreturn forest activities indicates that asset-poor households are more reliant on forest activities compared with the better off; reliance on high-return activities is conditioned also by availability of adult male labor and location. Taken together, the study's findings suggest that forests prevent poverty by supplementing income, and may also help to improve the living standards of households that are able to enter into high-return forest occupations. Policy implications are discussed.

JEL classification: I32; O13; Q12

Keywords: poverty, inequality, deforestation, income diversification, Malawi

Published in Environment and Development Economics, 2004, vol. 9, issue 2, 135-154. 


\section{Summary}

This paper examines economic reliance on forests and its effects on the welfare of lowincome households in rural Malawi. Three questions motivate the analyses. One, how dependent are sample households on forests for income? Two, does access to forests as a source of income impact income inequality at the study sites? And three, what are the determinants of economic reliance on forests, defined as the share of earnings derived from forest-based activities?

Data for the study come from a monthly survey of 99 households conducted in three villages in southern Malawi between June 1999 and August 2000 All of the sample households used firewood for cooking and heating, and 75 percent engaged in forest occupations including sales of firewood and charcoal and employment by the logging industry. Home-consumed firewood and earnings from forest-based occupations constitute substantial shares of household income. On average, sample households earned about 30 percent of their income from forests.

The Gini coefficient is a common measure of income inequality across individuals or households. For the sample households the Gini coefficient was computed and decomposed by six income sources: farm, forest, wage-work, self-employment, transfers, and remittances. The analysis shows that forest income reduced measured income inequality by 12 percent during the year of the study. This reflects a pattern in which firewood collected from adjacent forests represents an important input to household income for all sample households.

Further analysis examines the factors associated with dependence on forest earnings, distinguishing between low-return forest activities (LRFA), such as firewood marketing, and high-return forest activities (HRFA), such as logging employment. The distinction is important because the latter are intensive in the use of resources, but also 
hold promise for helping the poor move out of poverty over time. The analysis is conducted using a pair of Tobit models for earnings shares from LRFA and HRFA. Findings suggest that households poor in human capital and animal holdings are more reliant on LRFA and HRFA. Reliance on HRFA, however, is conditioned also by availability of adult male labor and location.

The main policy implication of the study is that forests may have a role in poverty alleviation in Malawi, but to reduce economy-environment tradeoffs, careful targeting and a mix of forest-based and other approaches to poverty alleviation is necessary. 


\section{Introduction}

A common narrative in policy discussions about development and the environment is that the poor are both agents and victims of environmental degradation (e.g. WCED 1987). The implication for forestry is that poverty alleviation can reduce forest pressure and development of forest resources can help alleviate poverty. This viewpoint has been highly influential—as evidenced by the large number of conservation-with-development projects implemented in recent years_-yet its apparent simplicity is misleading. The link between poverty and natural resources such as forests is indeterminate. There is limited evidence on the impact of poverty on deforestation, and studies reach different conclusions (for a review see Kaimowitz and Angelsen 1998). Likewise, forests have potentials and limitations for improving human welfare (Angelsen and Wunder 2003). Forests may prevent poverty (supplementing income and functioning as safety nets) or reduce poverty (with high earnings); but reliance on forest resources can also perpetuate poverty (for a review see Neumann and Hirsch 2000; Pattanayak and Sills 2001).

This paper explores the link from forests to poverty for the case of Malawi. In Malawi, as in other tropical countries, forests are increasingly viewed as an important vehicle for poverty alleviation. Its National Forestry Programme states that forests and trees can and should be used to eradicate poverty (GOM 2000). This study asks if forestled poverty reduction is possible, and whether economy-environment synergies or tradeoffs are more likely (Wunder 2001). The analysis begins by examining the ways in which forests contribute to household income and influence overall income distribution for a sample of rural households. Tobit models are used to identify factors associated with forest dependence, defined as the share of earnings derived from forest-based activities. The analysis distinguishes between low-return forest activities, which comprise smallscale commercialization of low-value forest products (e.g. firewood), and high-return 
activities, which involve marketing of high-value products (e.g. timber) as well as mass production of low-value goods (e.g. charcoal). The distinction is important because the latter are intensive in the use of resources, but also hold promise for helping the poor leave poverty over time. The conclusion highlights policy implications of the findings.

\section{Study context and data}

\subsection{Background on deforestation and forest policy in Malawi}

A recent estimate for Malawi's deforestation rate is 2.4 percent per annum, the highest for southern Africa (FAO 2001 cited in UNEP 2002). The interplay of high population density, poverty, forest reliance in rural areas, and weak forest management institutions create challenges to conservation of Malawi’s forests. Key forest threats are clearing for agricultural expansion and high demand for wood, particularly woodfuels (GOM 1998a).

The majority of Malawians are engaged in agriculture, cultivating less than a hectare of land on average (PMS 2000). Smallholder agriculture is characterized by low productivity due to slow adoption of improved techniques and the single short growing season each year (Ng'ong'ola et al. 1997). Farmers often have little option but to clear forest land to grow maize (the staple crop) and other crops to feed their families; and in many communities, customary land is open access due to weakened traditional controls over land allocation. ${ }^{1}$ In northern Malawi, shifting cultivation is still common, but demand for land exceeds supply in some areas (GOM 1998a). Forest clearing remains an obstacle to forest conservation in Malawi, though less so in recent years due to limited availability of arable land, especially in the south (GOM 1998b).

${ }^{1}$ Estates cleared large tracts of forest before 1994, under the former political regime. Today, estate expansion is controlled and has negligible forest impact (Probyn 2001). 
Tobacco and tea estates use of wood for curing and building storage sheds accounts for nearly 30 percent of total wood demand in Malawi. Rural and urban households' use of woodfuels for cooking and heating makes up an estimated two-thirds of wood consumption (GOM 1998a). In rural areas, firewood from adjacent forests remains an essentially free and accessible good, and low-cost alternative energy sources are generally not available (Brouwer 1998). In urban areas, poverty combined with rising tariffs on paraffin and electricity in recent years encourages people to use woodfuel for their domestic energy needs (GOM 1998a). Welfare poverty in rural areas means cheap labor is available to supply woodfuels at low cost, retarding the transition to non biomassbased fuels. Productivity of Malawi's natural forests, mostly miombo, is generally low; at current levels of demand, wood harvest rates exceed sustainable yield (GOM 1998b).

These and other contextual factors have led some observers to ask if the problem of deforestation in Malawi is “unsolvable” (French 1986). However, recent changes in the forest sector may offer hope for Malawi’s forests. Malawi’s National Environmental Action Plan (NEAP) includes many forest conservation programs: devolution of forest management roles to local communities in some forest areas, programs to intensify agriculture, fuel-saving cook stove programs, and so forth (GOM 1998b). Other recent developments include increased financial and technical support for conservation efforts from donors and non-governmental organizations (NGOs).

\subsection{Field sites and data}

Data for the study come from a household survey in three villages in southern Malawi, the region of the country that ranks highest in terms of poverty incidence, population density, and scarcity of forest resources (GOM 1998b; PMS 2000). Research villages were purposively selected to represent the main forest management types in 
Malawi; they also provide a spectrum of market access. ${ }^{2}$ Village 1 is 10 kilometers from a tarmac road and town and adjacent to the Mulanje Mountain Forest Reserve (MMFR), one of 71 gazetted forests managed by the Forestry Department, representing 22 percent of forest cover in Malawi. ${ }^{3}$ Households in this village have access to relatively abundant forest resources and markets for non-timber forest products (NTFPs) and timber. In Village 2, woodland on customary land is managed as a Village Forest Area (VFA) by the village head and a committee of village leaders. In Malawi, 50 percent of forest area is on customary land (GOM 1998a). The VFA system, in which communities set aside woodland areas for conservation purposes, was initiated in the 1920s and rekindled recently by the Forestry Department (Place and Otsuka 1997). Located 20 kilometers from a tarmac road and town, Village 2 is remote, but is close to Mozambique (5 kilometers), where agricultural and forest goods can be purchased at prices below those in Malawi. The little remaining woodland on customary land in Village 3 is de facto open access due to the breakdown of traditional authority in recent years, characteristic of many customary forests in Malawi (Place and Otsuka 1997). Village 3 is adjacent to a tarmac road linking it to Blantyre (Malawi’s largest city) 40 kilometers away. Most charcoal sold in Malawi’s major cities is produced by local people in surrounding rural areas (Makungwa 1997). Charcoal marketing is common in Village 3. Table 1 summarizes key characteristics of the study villages.

${ }^{2}$ Purposive samples are common when researchers want to collect in-depth, reliable data in a small geographical area. Since the research villages were selected purposively, the extent to which the data are generalizable to southern Malawi is not known. That being said, there is no reason to believe the study villages are anomalies.

${ }^{3}$ Since 2001 the forest has been co-managed by local people and Forestry Department. 
Within villages, 99 households were randomly selected, representing 12 percent of the total population in the three villages. Household residents were interviewed monthly from June 1999 to August 2000 on a range of topics, mainly forest use. Some of the methods used to ensure the collection of quality data are: close supervision of enumerators by the author, interviews with groups of household residents to obtain more complete information, and separate interviews with men and women when this was judged to be conducive to respondents' willingness to disclose sensitive data

\section{Forest contributions to aggregate income and a more equal income distribution}

\subsection{Forest contributions to aggregate income at the study sites}

Table 2 presents earnings and income shares by source for the sample households. The household income accounts are described in the Appendix and Fisher (2002). The table indicates that income diversification was common at the study sites, in line with other observations in rural Africa (Barrett et al. 2001). Where markets for credit and insurance are missing or thin, diversification is often important for ex ante risk mitigation, coping with adverse shocks, and earning the cash needed to buy farm inputs or make investments (Barrett et al. 2001). All households in the sample received income from several sources.

Table 2 shows high earnings shares from forests in Villages 1 and 3, in part a reflection of high participation rates: 82 percent and 73 percent of households in Villages 1 and 3 reported forest-based earnings in 1999/2000. Why is forest use so prevalent? One explanation is the ease with which households can initiate forest enterprises; some, such as firewood sales, require only labor and ubiquitous tools. In both villages, forest access was somewhat unrestricted during the study year. The Forestry Department in Village 1 was unable to prevent villagers from extracting firewood at a level exceeding sustainable yield (Knacck Consultants 1999). In Village 3, forest resources on customary 
land are open access. The high forest earnings shares also reflect opportunities and high returns to some forest occupations arising from resource endowments and market access. The forest reserve near Village 1 has high-value timber and pine. Local people work as pit sawyers or plank transporters for timber merchants. A few better-off households sold planks to merchants. Village 3 households have access to urban charcoal markets.

The average share of earnings derived from forests by Village 2 households is lower than averages in the other villages. These differences are statistically significant; the calculated F-statistic from Analysis of Variance is 3.80, and a hypothesis of equal means can be rejected. There are several plausible explanations for observed inter-village differences. First, the headman in Village 2 appeared somewhat more successful at reducing forest access compared with the Forestry Department in Village 1 and the head in Village 3. Second, Village 2 has neither accessible timber, nor access to urban charcoal markets. Finally, self-employment activities competed with forest occupations in Village 2 due to proximity to Mozambique. A common, relatively lucrative occupation in Village 2 is to buy agricultural goods from Mozambican farmers to sell in Malawi.

Table 2 also reports average income shares by sector. In the income figures, farm income includes earnings from crop sales and the value of own-consumed maize production; forest income includes forest-based earnings and the value of own-consumed collected firewood. ${ }^{4}$ Inclusion of collected firewood in the household income accounts is

\footnotetext{
${ }^{4}$ A few shortcomings of the income data should be mentioned. First, retained maize and collected firewood represent the bulk of home consumption, but households did consume other crop production and other forest-collected products. Thus, farm and forest income are underestimated to some degree. Another source of measurement error is imputation of values where data are missing. See the Appendix and Fisher (2002) for more detail.
} 
important, because all sample households used collected wood for cooking and for 69 percent it was the dominant fuel. Simple calculations demonstrate the high value of collected firewood to household budgets. A family of four cooking three meals a day would use 6.3 kilograms of firewood on average (Brouwer 1998). Using an estimated local market price for firewood of Malawi Kwacha (MK) 1.09 per kilogram from a survey of firewood sellers $(\mathrm{N}=14)$, the annual cost to buy firewood would be MK2,925. ${ }^{5}$ This can be compared with the mean income of sample households during the survey year (MK14,698). Clearly, the value of collected forest products like firewood, often left out of household income accounts, is very important to rural Malawians.

In sum, the data show that forest income accounted for about 30 percent of household income on average, a figure that is not unprecedented. A detailed survey of environmental resource use in Zimbabwe found that extraction contributed 35 percent of rural household income on average (Cavendish 1999). Godoy et al. (2002) report that earnings from forest activities accounted for 17 to 45 percent of household earnings, on average, across four Amerindian villages in the Bolivian lowlands and eastern Honduras.

\subsection{Forest contributions to a more equal income distribution at the study sites}

High participation rates in forest occupations and the importance of forest-collected firewood to households budgets may indicate that access to forests as a source of income reduces income inequality at the study sites. To examine this, measured income inequality is decomposed by income source, which is indexed by $i$. Note that in the current context, the term “income” refers to "income per household resident”. The Gini coefficient $(G)$ decomposed into its income source components is given by (Yao 1999):

\footnotetext{
${ }^{5}$ During the survey year, the exchange rate was about $50 \mathrm{MK}=\mathrm{US} \$ 1$.
} 


$$
G=\sum_{i=1}^{I} w_{i} C_{i}
$$

where $I$ is the total number of source incomes $i$ and $w_{i}$ represents the share of source income $i$ in aggregate household income. $C_{i}$, the concentration ratio of source $i$, is:

$$
C_{i}=1-\sum_{j=1}^{N} p_{j} 2\left(Q_{i j}-w_{i j}\right)
$$

where $p_{j}$ is the population share of household $j$ in the total population and $w_{i j}$ is the income share of household $j$ for source $i$. The variable $Q_{i j}$ is the cumulative income share up to household $j$ for income source $i$ defined by:

$$
Q_{i j}=\sum_{k=1}^{j} w_{i k}
$$

For each source income $i$, the concentration ratio $\left(C_{i}\right)$ is computed using equation (3) relying on observations sorted in ascending order of aggregate income. I calculate source income Gini coefficients $\left(G_{i} \mathrm{~S}\right)$ using equation (2) sorting observations in ascending order of the given source income $i$. The Gini coefficient for aggregate income is calculated with equation (1).

Results are presented in Table 3. The first row of the table provides Gini coefficients by source income and aggregate income. The aggregate income Gini is 0.49. The World Bank (1995) has estimated the Gini coefficient for rural Malawi smallholders to be $0.57,14$ percent higher than the estimate here. One possible source of discrepancy is measurement error in the household survey data. It is also possible that the World Bank's estimate is based on a measure of income that did not include forest resources. The income data used by the World Bank come from Malawi’s National Sample Survey of Agriculture (1992/93). It is unlikely that the survey collected information on homeconsumed forest products. If forest income sources are excluded from the analysis here, the estimated Gini coefficient is 0.56 , very close to the World Bank's estimate. Figure 1 
illustrates the impact of forest income on income inequality. The diagonal line denotes perfect inequality. Lorenz curves are constructed with the data for household income including and excluding forest income. The figure shows that addition of forest income to household income reduces measured income inequality by 12 percent, all else equal.

Turning to the source income Gini coefficients, each is higher than the aggregate income Gini, indicating that diversification of income reduces income inequality across the sample. However, not all income sources reduce income inequality. The second row of Table 3 gives the share of total income inequality attributed to each income source. Forest and farm income contributed the largest shares to total income inequality, largely because income from these sources made up high shares of aggregate income (see row four of the table). To assess whether a given source of income reduces or increases income inequality, refer to equation (1). All else being equal, if $C_{i}>G$ and the share of source income $\left(w_{i}\right)$ is increased (decreased), then income inequality $(G)$ will increase (decrease). This implies that sources of income with concentration ratios $\left(C_{i}\right)$ with values lower than 0.49 (the aggregate income Gini) help reduce total income inequality. Results in the third row of Table 3 indicate that, all else being equal, an increased share of income from the forest or the farm would lower income inequality at the study sites; increased income shares from other sources would yield higher income inequality.

The data suggest that forests offer a more egalitarian source of income compared with most other sources at the study sites. This is no surprise since collected firewood from adjacent forests represents an important income input for all sample households. In addition, participation in forest occupations is common at the study sites. The finding that forest income lowers income inequality is consistent with other studies. Cavendish (1999) finds that environmental income reduced measured inequality by 20 to 30 percent for his sample of Zimbabwean smallholders. Reddy and Chakravarty (1999) found that 
forest income was associated with a small reduction in income inequality for a sample of northern Indian farmers. The analysis here is one of the first to measure how forest income influences aggregate income inequality with use of decomposed Gini measures.

\section{Determinants of forest reliance}

\subsection{Categorizing forest activities}

In the previous section of the paper forest occupations were viewed as a homogenous group to assess the overall contribution of forest resources to household welfare at the study sites. The mix of forest activities and the factors that shape reliance on them can vary considerably, however, even within a small geographical area (Byron and Arnold 1999; Coomes et al. forthcoming; Godoy et al. 2002). Participation rates and earnings shares for the various forest activities present at the study sites are shown in Table 4 in ascending order of average annual earnings. Forest activities can be loosely categorized into two groups: low-return (LRFA) and high-return forest activities (HRFA). Mean yearly earnings range from MK626 to MK4,895 for the LRFA and MK5,705 to MK21,710 for the HRFA. Average annual earnings for contract agricultural labor (a lowreturn activity) and permanent wage-work (high-return activities) are MK2,103 and MK12,980 respectively. The LRFA/HRFA classification is useful for two reasons. First, prospects for forest-led poverty alleviation should differ importantly for the two groups. Second, the activity categories differ considerably in terms of environmental impact.

Table 5 presents pair-wise correlations between the share of earnings from forest activities and income and consumption measures. I use as a comparison group the 12 sample households engaged in remunerative, permanent wage-work. The first column of the table shows a negative correlation between measured income and reliance on LRFA, consistent with the extant literature (for a review see Neumann and Hirsch 2000). 
Depending on whether one views income (or wealth) as exogenous or endogenous, one can argue that a negative correlation between wealth and forest reliance implies that forests provide safety nets or are poverty traps (Angelsen and Wunder 2003). At best, reliance on LRFA helps the poor survive poverty, but is unlikely to reduce poverty.

The second and third columns of Table 5 show positive correlations between measured income and earnings shares from HRFA and wage-work during the survey year. This positive correlation can be viewed as indicating that participation in HRFA leads to relatively high income and/or that relatively high income enables entry into remunerative forest occupations. HRFA may hold promise for reducing poverty, but this depends on the ability of the poor to enter activities, and the time path of opportunities. I empirically examine the former issue below, and discuss the latter in the conclusion.

A second important distinction between HRFA and LRFA is that the former are generally more degrading of forest resources than the latter. Commercialization of NTFPs may have negligible ecological impact in the study area (Konstant 1999). Firewood collection is an exception, however. Interviews with local people suggest overharvesting; with each passing year women must travel further to collection sites (Fisher 2002; Konstant 1999). There is also evidence of destructive harvesting techniquesreports of trees being felled for firewood and collectors destroying coppices from stumps and saplings, which are required for natural regeneration (Knacck Consultants 1999).

From an environmental standpoint, the most worrisome commercial forest activities in the study area are charcoal production and timber extraction. Charcoal production involves clear-felling of indigenous trees on customary land, resulting in soil erosion, loss of habitat for plant and animal species, and reduced availability of wood (GOM 1998b; Makungwa 1997). Gardens are opened up when trees are felled for charcoal burning; however, much of the remaining forest land in southern Malawi is not 
suitable for agriculture (GOM 1998b). Timber extraction in the forest reserve adjacent to Village 1 is also a key concern from an environmental perspective. The bulk of extracted timber comes from government pine plantations, but illegal harvesting of protected trees such as Mulanje cedar and other threatened indigenous species is reducing biodiversity and affecting the microclimate, for example (Knacck Consultants 1999).

The above discussion highlights potential economy-environment tradeoffs in southern Malawi. At issue is that charcoal burning and timber extraction are remunerative activities that may enable poverty reduction, at least in the short term, but these activities have adverse environmental effects. This is an issue of considerable relevance to policy interventions; I return to it in the concluding section of the paper.

\subsection{Empirical Analysis}

I turn now to an empirical investigation of the factors associated with forest dependence, defined as the share of earnings from forest activities. Data on earnings presented above reveal considerable differences across forest income sources and suggest that various circumstances give rise to forest reliance. In general, dependence on HRFA should be more a matter of choice, a response to opportunities for gainful employment. By contrast, reliance on LRFA may indicate necessity or lack of better options. Whether households are pulled or pushed into the forest sector should in large part reflect the composition of their asset holdings. In the analysis that follows, I examine whether differences in asset positions are key determinants of reliance on LRFA versus HRFA.

Two equations are estimated, one for dependence on LRFA (Model 1), the other for dependence on HRFA (Model 2). In each case, I employ Tobit models because some households did not have earnings from forest occupations. The Tobit technique accounts for censoring in the dependent variables. Explanatory variables are: natural log of 
relative returns to labor in forest activities and maize production, farm size per capita, number of adult male household residents, goat ownership, age and education of the household head, and village of residence. ${ }^{6}$ Model specification draws on Reardon and Vosti’s (1995) conceptual framework of low-income farm households’ decisions impacting the environment. In the framework, household behavior is a function of the components of household assets (natural resource, human resource, physical, and financial) and external conditioning factors (markets, policies, technologies, prices, institutions, and community assets). Asset decomposition is important where markets (e.g. for credit, insurance, and labor) fail or function poorly, as is the case in rural Malawi. In these settings, fungibility of assets is limited and asset-specific poverty can influence resource use and investment decisions (Coomes et al. forthcoming).

Tobit model results are presented in Table $6 .^{7}$ In both regressions several key point estimates are individually and jointly different from zero at a 90 percent confidence level. Patterns of significance differ slightly across regressions, however.

${ }^{6}$ The price of maize is observed only in households that sold maize and hourly returns to forest occupations are observed only in households engaging in these activities. But even when a household chooses not to participate in a given activity, it faces an opportunity price in that sector. For this reason, omitting observations from the equations due to missing price data would bias our results. We impute missing prices and net hourly returns with sub-sample ordinary least squares (OLS). See Fisher (2002) for details. ${ }^{7}$ Diagnostic tests indicate heteroscedasticity in Model 1. Thus, results reported for Model 1 in Table 6 account for multiplicative heteroscedasticity with respect to: natural $\log$ of returns ratio, farm size per capita, secondary education of the household head, and 
As expected, households with higher relative returns to forest occupations had higher forest earnings shares, all else equal. This is true for both HRFA and LRFA. Farm size per household resident should provide a good indication of availability of excess labor to employ off farm and the household's level of food security (Peters 1996). Thus, households with relatively small landholdings per capita have both the capacity and the need to engage in forest activities. Results show a negative correlation between farm size per capita and forest reliance, consistent with patterns reported in Peru (Coomes et al. forthcoming). The point estimate is statistically weak, however, for HRFA.

At the study sites, forest activities are labor intensive in general, but the need for adult male labor is crucial for participation in HRFA. Charcoal burning tends to be malespecific in southern Malawi, although small numbers of women do participate, either assisting their husbands or on their own (usually female heads of household) (Makungwa 1997). Likewise, only men were employed as plank sawyers and transporters in the forest reserve. Thus, a variable for the number of men in the household is included in the regressions. Findings show a positive association between number of men and the share of earnings from HRFA. The association is positive but statistically weak for LRFA. In rural Africa, livestock acquisition remains a key form of wealth accumulation (Dercon 1998). In southern Malawi, cattle rearing is limited by land scarcity. Data from Malawi’s Integrated Household Survey $(\mathrm{N}=10,698)$ show that only 3.7 percent of households in the south owned cattle; goat ownership is more common (20 percent of households) (PMS 2000). Goats are a relatively liquid asset that can be sold in response to price signals, to smooth consumption, or to provide financial capital to start a business.

head aged 35-44 years. I tested for multicollinearity using variance inflation factors (VIF). The VIFs do not suggest harmful collinearity; the largest VIF had a value of 1.45. 
Results show a negative correlation between number of goats owned at the start of the survey year and the share of earnings from LRFA and HRFA. ${ }^{8}$ The former is as expected, households that own more goats should have less need to engage in low-return activities. The finding of a negative association between goat ownership and reliance on HRFA, however, is somewhat of a surprise and may indicate low requirements of financial capital for engaging in HRFA.

To assess the extent to which forest reliance changes over the life cycle of the household head, I include in the regressions binary variables indicating age of the household head by category. ${ }^{9} \quad$ Results suggest that households with a head aged 45 plus were more reliant on LRFA compared with those households with a head aged 33 to 44 years; there is little statistical support for a hypothesis that age affects reliance on HRFA.

HRFA activities are relatively lucrative, but risky and laborious. Charcoal marketing is illegal in Malawi and discussions with entrepreneurs revealed that charcoal is confiscated by the police about once a month. Pit sawing is physically demanding, as is carrying planks upon one's head from sawing sites on the mountain down to the road, a precarious task in the rainy season. Those with opportunities to engage in less risky, remunerative jobs, such as permanent wage-work, should be less reliant on forests for income. Education may signal one's potential productivity to employers, increasing the

\footnotetext{
${ }^{8}$ The discussion suggests that wealth is a determinant activity choice (and subsequent earnings); it could also be argued that activity choice conditions wealth accumulation. While wealth is usually endogenous to wages, endogeneity may be less of an issue for the sample data since goat ownership is observed prior to the labor allocation decision. ${ }^{9}$ Age is categorical because respondents generally were not aware of their age. Our approach was to estimate age by reference to a list of historical events.
} 
likelihood of being hired into attractive labor markets. Thus, I include a binary variable indicating secondary school attendance of the household head. As expected, results indicate a negative association between secondary education and forest reliance.

Binary variables for Village 1 and Village 3 residence were included to capture differences in market access and natural resource endowments that condition forest sector opportunities across villages. Village effects are statistically weak for Model 1, likely due to the ubiquity of LRFA. As expected, the share of earnings from HRFA is higher in Villages 1 and 3 compared with Village 2.

In sum, regression results for Model 1 suggest that households that are poor in land, education, and goat holdings are more reliant on LRFA. This is consistent with studies of income diversification in Africa which show that asset poverty compels diversification into low-return activities (Barrett et al. 2001; Dercon 1998). Unfortunately, as shown in Table 5, reliance on LRFA was associated with lower measured income over the course of the survey year. Participation in LRFA therefore did not reduce poverty during the survey year, though it may have helped the poor survive their poverty, providing supplementary income and a means to cope with adverse shocks.

Regression results for Model 2 show a negative correlation between educational attainment (secondary education) and livestock wealth (goats) and reliance on HRFA. Key factors that constrain some households from taking advantage of opportunities for gainful employment are limited availability of adult male labor and residence in Village 2 (where there is neither high-value timber, nor access to urban woodfuels markets). Thus, households that are poor in some assets (education and animal holdings), but well endowed in others (men and community assets) can participate in and earn high earnings shares from remunerative forest occupations. There may be prospects for forest-led poverty reduction in rural Malawi, given the results here and the positive correlation 
between reliance on HRFA and income (see Table 5). This statement must be qualified. The data concern a single year-a random snapshot of forest-people relationships which can vary considerably across years (Campbell et al. 2002; McSweeney 2002). In addition, the data are for a small sample of households that may or may not be representative of rural Malawi. There is a need for future work using a nationallyrepresentative panel dataset to better explore the patterns observed in the current study.

\section{Conclusions and Policy Implications}

This paper reveals and quantifies the important role forests play in alleviating poverty in rural Malawi. The data indicate high levels of dependence on forests for income; sample households derive about 30 percent of income from forests on average. The data also suggest that access to forests may reduce income inequality across households; the addition of forest income to the household accounts leads to a 12 percent reduction in measured income inequality. Regression results show that asset-poor households are more reliant on LRFA and HRFA, compared with the better off; reliance on HRFA is also conditioned by availability of adult male labor and location. Taken together, the study's findings suggest that forests prevent poverty, and may reduce poverty for households that are able to enter into HRFA. Future work using a nationally-representative panel dataset is needed to better assess the extent to which access to forest income in rural Malawi can help the poor improve their economic status over time, and to more directly investigate the relationship between growth in the forest sector and income distribution.

The main policy implication of the study is that forests may have a role in poverty alleviation in Malawi, but to reduce economy-environment tradeoffs, careful targeting and a mix of forest-based and other approaches to poverty alleviation is necessary. Results indicate that asset-poor households are reliant on LRFA for earnings; these 
activities supplement income and may also buffer adverse shocks. Efforts to conserve Malawi's forests, such as restricted access, might lead to reduced welfare because of the high reliance on LRFA among the poor. However, forest protection could in fact benefit the poor if it leads to a rise in prices of NTFPs, for example. More importantly, policies that focus on securing forest access by the poor and maintaining them in LRFA may actually perpetuate poverty, if other development options are overlooked (Angelsen and Wunder 2003). A more effective pro-poor (and pro-forest) strategy may be one that assists the poor in moving out of LRFA and into more gainful employment. Towards this end, public investment in the (non-forest) wage-work and self-employment sectors may be warranted, for example educational spending, food-for-work interventions, and microlending programs. Forest-based approaches, such as market development for underexploited products like wood and bamboo crafts may be more cost-effective, however. Such programs can increase local incentives to sustainably manage forest resources on which enterprises depend. But careful implementation is necessary, because the rise in value of NTFPs may spur over-harvesting of resources (Neumann and Hirsch 2000).

Study findings indicate potential for forest-led poverty reduction through participation in HRFA. These opportunities should continue in the near future. Charcoal marketing to urban consumers seems assured in the next few years due to recent elimination of subsidies, rising tariffs on parrafin and electricity, and rapid population growth in Malawi’s urban areas (GOM 1998a; UNCHS 2001 cited in UNEP 2002). The FAO predicts an increase in demand for woodfuels in Africa greater than 45 percent over the next 30 years (FAO 2001 cited in UNEP 2002). Likewise, urban population growth should stimulate demand for wood for construction and furniture making.

Economy-environment tradeoffs may be acute. HRFA provide gainful employment but also have adverse environmental impacts. Restricted forest access may 
be necessary to avoid excessive resource depletion, but this presents a clear challenge. The Malawi government banned charcoal burning in the 1990s, but this has done little to curb production (Makungwa 1997). Likewise, illegal logging occurs in forest reserves despite high fines imposed on violators (Knacck Consultants 1999).

Synergies between poverty reduction and forest conservation may be fostered by programs that encourage the planting and use of trees outside of natural forests. One possibility is community-company forestry partnerships; these have proven useful for conserving forests and improving rural welfare in many areas (Scherr et al. 2002). Companies typically provide necessary materials, low-interest loans, and technical assistance for establishing and managing small woodlots on farm or customary land. In return, companies have rights to buy the mature trees. The feasibility of such programs in land-scarce areas such as Malawi requires further investigation. Another option is to make use of currently under-utilized eucalyptus timber supplies in government plantations (as has been suggested by some analysts—see Knacck Consultants 1999). Technical assistance for more efficient charcoal production technologies will also be important. Perhaps the greatest challenges will be faced by village heads and rural communities, to organize and collectively establish and enforce rules limiting charcoal burning and timber harvesting in natural forests on customary land. 


\section{Appendix - The household income accounts}

Household income is the sum of earnings from all sources and home consumption, in September 2000 MK. Earnings data are complete. Home consumption is retained maize and collected firewood used for cooking; values were imputed where the data are missing. Imputations are described briefly below and in detail in Fisher (2002).

Maize output data for 2000 are available for 68 households. A Cobb-Douglas production function was estimated using data for the sub-sample. Regression coefficients and observed data were used to impute maize output for 31 missing observations. Mean maize output for the sample (imputed and observed values) is 423 kilograms. This amount of maize would feed a family for about six months (The Lamp 1999). The sixmonth self-sufficiency estimate agrees well with other estimates for southern Malawi (e.g. Orr and Mwale 2001). To estimate retained maize for sample households, I subtracted from maize output the quantity of (after-harvest) sales of maize, available from the earnings accounts. The quantity of retained maize was valued using a price of MK7.42 per kilogram (European Food Security Network 1999, 2000).

The value of collected firewood for cooking was estimated. Using data from direct measurements with a sub-sample of households $(\mathrm{N}=18)$, I obtained an estimate of 0.49 kilograms of firewood per person per meal. This figure agrees well with Brouwer’s (1998) corresponding estimate. To obtain household-specific estimates for firewood used for cooking in 1999/2000, I used data for household population, number of meals cooked per day (available monthly), and the dominant cooking fuel used. Assumptions (based on field observations) about the number of months firewood was used were required for households reporting that harvest residues or purchased wood were dominant fuel sources. Estimated firewood quantities were valued at MK1.09 per kilogram, the average price received by firewood sellers $(\mathrm{N}=14)$ at a survey area market in February 2000. 


\section{References}

Angelsen, A. and S. Wunder (2003), 'Exploring the forest-poverty link: key concepts, issues and research implications’, CIFOR Occasional Paper No. 40, Center for International Forestry Research, Bogor, Indonesia.

Barrett, C.B., T. Reardon, and P. Webb (2001), 'Nonfarm income diversification and household livelihood strategies in rural Africa: concepts, dynamics and policy implications’, Food Policy 26: 315-331.

Brouwer, I.D. (1998), 'When households run out of fuel: responses of rural women in Malawi to decreasing fuelwood availability’, Energia 2: 1-6.

Byron, N. and M. Arnold (1999), 'What futures for the people of tropical forests?', World Development 27: 789-805.

Campbell, B.M., S. Jeffrey, M. Luckert, M. Mutamba, and C. Zindi (2002), 'Household livelihoods in semi-arid regions: options and constraints', Center for International Forestry Research, Bogor, Indonesia.

Cavendish, W. (1999), 'Poverty, inequality and environmental resources: quantitative analysis of rural households', Working Paper Series No. 99-9, Center for the Study of African Economies, Oxford.

Coomes, O.T., B.L. Barham, and Y. Takasaki (forthcoming), ‘Targeting conservationdevelopment initiatives in tropical forests: insights from analyses of rain forest use and economic reliance among Amazonian peasants’, Ecological Economics.

Dercon, S. (1998), 'Wealth, risk and activity choice: cattle in western Tanzania’, Journal of Development Economics 55: 1-42.

European Food Security Network (1999, 2000), 'Monthly brief Malawi - Mozambique’, http://europa.eu.int/comm/europeaid/projects/resal. 
Fisher, M.G. (2002), ‘Explaining forest degradation in Malawi: asset poverty, income shocks, and activity choice’, Unpublished Ph.D. dissertation, Department of Agricultural Economics, Purdue University, West Lafayette, Indiana.

French, D. (1986), 'Confronting an unsolvable problem: deforestation in Malawi’, World Development 14: 531-540.

Godoy, R., H. Overman, J. Demmer, L. Apaza, E. Byron, T. Huanca, E. Perez, V. ReyesGarcia, V. Vadez, A. Cubas, K. McSweeney, and N. Brokaw (2002), ‘Local financial benefits of rain forests: comparative evidence from Amerindian societies in Bolivia and Honduras’, Ecological Economics 40: 397-409.

Government of Malawi (GOM) (1998a), 'State of the environment report for Malawi 1998’, Environmental Affairs Department, Lilongwe, Malawi.

Government of Malawi (GOM) (1998b), ‘The national environmental action plan’, Sustainable Development Network Program, http://www.sdnp.org.mw/enviro/index.html.

Government of Malawi (GOM) (2000), ‘Malawi’s National Forestry Programme’, Department of Forestry, Lilongwe, Malawi.

Greene, W.H. (2000), Econometric Analysis, Fourth Edition, New York: Macmillan Publishing Company.

Kaimowitz, D. and A. Angelsen (1998), 'Economic models of tropical deforestation: a review’, Center for International Forestry Research, Bogor, Indonesia.

Knacck Consultants (1999), ‘Timber utilization consultancy’, Consultancy report for the Mulanje Mountain Conservation Trust, Mulanje, Malawi.

Konstant, T. (1999), 'Non-timber forest products: current and potential value on Mulanje Mountain', Consultancy report for the Mulanje Mountain Conservation Trust, Mulanje, Malawi. 
The Lamp (no author specified) (1999), 'Malawi’s breadbasket 1999’, The Lamp NonPartisan Magazine 16: 13.

Makungwa, S.D. (1997), 'Charcoal production study in Blantyre area', Report for the Forestry Research Institute of Malawi, Zomba, Malawi.

McSweeney, K. (2002), ‘Who is forest dependent? Capturing local variation in forestproduct sale, Eastern Honduras’, The Professional Geographer 54: 158-174.

Neumann, R.P. and E. Hirsch (2000). ‘Commercialization of non-timber forest products: review and analysis of research', Center for International Forestry Research, Bogor, Indonesia.

Ng’ong’ola, D.H., R.N. Kachule, and P.H. Kabambe (1997), ‘The maize, fertilizer, and maize seed markets in Malawi', Report submitted to the International Food Policy Research Institute, Washington, D.C.

Orr, A. and B. Mwale (2001), 'Adapting to adjustment: smallholder livelihood strategies in southern Malawi’, World Development 29: 1325-1343.

Pattanayak, S.K and E.O. Sills (2001), 'Do tropical forests provide natural insurance? The microeconomics of non-timber forest product collection in the Brazilian Amazon’, Land Economics 77: 595-612.

Peters, P.E. (1996), 'Failed magic or social context? Market liberalization and the rural poor in Malawi', Development Discussion Paper No. 562, Harvard Institute for International Development, Cambridge.

PMS (2000), 'Profile of poverty in Malawi: poverty analysis of the Malawi Integrated Household Survey, 1997-98’, Poverty Monitoring System, Lilongwe, Malawi. 
Place, F. and K. Otsuka (1997), 'Population, land tenure, and natural resource management: the case of customary land area in Malawi', Environment and Production Technology Division Discussion Paper No. 27, International Food Policy Research Institute, Washington, D.C.

Probyn, J. (2001), Personal communication (via email) with development consultant for the Wildlife and Environmental Society of Malawi, Zomba, Malawi.

Reardon, T. and S. Vosti (1995), 'Links between rural poverty and the environment in developing countries: asset categories and investment poverty’, World Development 23: 1495-1506.

Reddy, S.R.C. and S.P. Chakravarty (1999), 'Forest dependence and income distribution in a subsistence economy: evidence from India’, World Development 27: 11411149.

Scherr, S.J., A. White, and D. Kaimowitz (2002), 'Making markets work for forest communities’, Forest Trends Policy Brief, Washington, D.C.

United Nations Environment Programme (UNEP) (2002), 'Africa environment outlook: past, present and future perspectives', http://www.unep.org/aeo/index.htm.

World Bank (1995), 'Malawi human resources and poverty: profile and priorities for action’, http://poverty.worldbank.org/library/view/8701/.

World Commission on Environment and Development (WCED) (1987), Our Common Future, Oxford: Oxford University Press.

Wunder, S. (2001), 'Poverty alleviation and tropical forests - what scope for synergies?', World Development 29: 1817-1833.

Yao, S. (1999), 'On the decomposition of Gini coefficients by population class and income source: a spreadsheet approach and application’, Applied Economics 31: 1249-1264. 
Table 1. Key characteristics of the research villages

\begin{tabular}{|c|c|c|c|}
\hline & Village 1 & Village 2 & Village 3 \\
\hline $\begin{array}{l}\text { Main source of } \\
\text { forest resources }\end{array}$ & $\begin{array}{l}\text { Mulanje Mountain } \\
\text { covering } 640 \mathrm{~km}^{2} \\
\text { comprising miombo } \\
\text { woodland and afro- } \\
\text { montane forest, and } \\
\text { pine plantations. } \\
\text { Degradation is most } \\
\text { pronounced in the } \\
\text { lowlands close to } \\
\text { human settlement. }\end{array}$ & $\begin{array}{l}\text { A hill covering } 16 \\
\mathrm{~km}^{2} \text { comprising } \\
\text { miombo woodland } \\
\text { and exotic trees, } \\
\text { mainly eucalyptus. }\end{array}$ & $\begin{array}{l}\text { Sparse collections } \\
\text { of trees of miombo } \\
\text { species. } \\
\text { Some villagers } \\
\text { walked to Mwanza } \\
\text { District, where } \\
\text { forest resources are } \\
\text { more plentiful, to } \\
\text { buy firewood and } \\
\text { charcoal for resale. }\end{array}$ \\
\hline $\begin{array}{l}\text { Forest products } \\
\text { available }\end{array}$ & $\begin{array}{l}\text { Most plentiful of the } \\
\text { villages: timber and } \\
\text { a wide-range of non- } \\
\text { timber forest } \\
\text { products (NTFPs) } \\
\text { (firewood, fruit, } \\
\text { mushrooms, bush } \\
\text { meat, insects). }\end{array}$ & $\begin{array}{l}\text { Mostly NTFPs: } \\
\text { firewood, bamboo, } \\
\text { fruit, mushrooms, } \\
\text { some bush meat, } \\
\text { insects, honey. }\end{array}$ & $\begin{array}{l}\text { Mostly firewood; } \\
\text { some villagers } \\
\text { cleared woodland to } \\
\text { expand their } \\
\text { gardens and/or burn } \\
\text { charcoal. }\end{array}$ \\
\hline $\begin{array}{l}\text { Forest management } \\
\text { regime }\end{array}$ & $\begin{array}{l}\text { State management } \\
\text { (Forestry } \\
\text { Department) }\end{array}$ & $\begin{array}{l}\text { Village forest area } \\
\text { (customary land) }\end{array}$ & $\begin{array}{l}\text { De facto open } \\
\text { access (customary } \\
\text { land) }\end{array}$ \\
\hline $\begin{array}{l}\text { Access to markets } \\
\text { for forest products }\end{array}$ & $\begin{array}{l}\text { Several local } \\
\text { markets within } \\
\text { walking distance } \\
\text { where firewood is } \\
\text { sold. } \\
\text { Possibilities to } \\
\text { market timber to } \\
\text { urban merchants. }\end{array}$ & $\begin{array}{l}\text { Opportunities to buy } \\
\text { firewood in } \\
\text { Mozambique ( } 5 \\
\text { kilometers) at prices } \\
\text { below those in } \\
\text { Malawi. }\end{array}$ & $\begin{array}{l}\text { Access to urban } \\
\text { charcoal and } \\
\text { firewood markets } \\
\text { (Blantyre, Malawi's } \\
\text { largest urban center, } \\
\text { is } 40 \text { kilometers } \\
\text { away). }\end{array}$ \\
\hline Distance to tarmac & 10 kilometers & 20 kilometers & 0 kilometers \\
\hline Important crops & $\begin{array}{l}\text { Maize (staple crop), } \\
\text { sorghum, pigeon } \\
\text { pea, velvet bean, } \\
\text { pumpkin. }\end{array}$ & $\begin{array}{l}\text { Maize and cassava } \\
\text { (staple crops), } \\
\text { sorghum, pigeon } \\
\text { pea, sweet potato, } \\
\text { pumpkin. }\end{array}$ & $\begin{array}{l}\text { Maize (staple crop), } \\
\text { groundnut, pigeon } \\
\text { pea, pumpkin. }\end{array}$ \\
\hline
\end{tabular}


Table 2. Earnings and income shares by source and by village, sample households $1999 / 2000$

\begin{tabular}{lrrrrrr}
\hline & Forest $^{\mathrm{a}}$ & Farm $^{\mathrm{b}}$ & $\begin{array}{c}\text { Self-empl. } \\
\mathrm{c}\end{array}$ & $\begin{array}{c}\text { Wage- } \\
\text { work }\end{array}$ & $\begin{array}{c}\text { Sales } \\
\text { assets }\end{array}$ & $\begin{array}{c}\text { Transfers } \\
\mathrm{f}\end{array}$ \\
\hline Earnings & & & & & & \\
Village 1 & 0.37 & 0.11 & 0.04 & 0.23 & 0.05 & 0.20 \\
(N = 39) & $(0-1.00)$ & $(0-0.88)$ & $(0-0.97)$ & $(0-0.96)$ & $(0-0.46)$ & $(0-0.99)$ \\
Village 2 & 0.20 & 0.23 & 0.22 & 0.09 & 0.07 & 0.19 \\
(N = 38) & $(0-0.89)$ & $(0-0.93)$ & $(0-0.95)$ & $(0-0.68)$ & $(0-0.34)$ & $(0-1.00)$ \\
Village 3 & 0.41 & 0.08 & 0.09 & 0.26 & 0.07 & 0.09 \\
(N = 22) & $(0-0.97)$ & $(0-0.38)$ & $(0-0.64)$ & $(0-0.97)$ & $(0-0.75)$ & $(0-0.71)$ \\
Full sample & 0.31 & 0.15 & 0.12 & 0.18 & 0.06 & 0.17 \\
Total income & & & & & & \\
Village 1 & 0.38 & 0.35 & 0.03 & 0.10 & 0.02 & 0.11 \\
(N = 39) & $(0.05-0.85)$ & $(0.05-0.77)$ & $(0-0.75)$ & $(0-0.52)$ & $(0-0.14)$ & $(0-0.77)$ \\
Village 2 & 0.21 & 0.42 & 0.15 & 0.06 & 0.04 & 0.11 \\
(N = 38) & $(0.01-0.80)$ & $(0.07-0.91)$ & $(0-0.77)$ & $(0-0.44)$ & $(0-0.29)$ & $(0-0.64)$ \\
Village 3 & 0.41 & 0.25 & 0.06 & 0.18 & 0.05 & 0.05 \\
(N = 22) & $(0.04-0.96)$ & $(0.02-0.58)$ & $(0-0.43)$ & $(0-0.83)$ & $(0-0.58)$ & $(0-0.31)$ \\
Full sample & 0.33 & 0.36 & 0.08 & 0.10 & 0.03 & 0.10 \\
\hline
\end{tabular}

a. Earnings/profits from forest-dependent income-generating activities (see Table 4).

b. Earnings from sales of crops including fruit crops (e.g. bananas).

c. Includes non forest-based businesses: resale of agricultural commodities, tailor, money lending, sales of fish, grocery sales, public transport operation, radio and bike repair, tinsmith, and stone breaking.

d. Includes non forest off-farm employment: contract agricultural labor (weeding, field preparation), forestry officer, teacher, mechanic, watchman, and village headperson.

e. Sales of livestock (cattle, goats, pigs) and poultry, property rental, and sales of personal and household items (radio, bicycle parts, clothing, etc.).

f. Remittances from household residents (mainly husbands working elsewhere), gifts from relatives, and loans. 
Table 3. Decomposition of income inequality by income source, sample households $1999 / 2000$

\begin{tabular}{|c|c|c|c|c|c|c|c|}
\hline & Forest & Farm & $\begin{array}{l}\text { Wage- } \\
\text { work }\end{array}$ & $\begin{array}{l}\text { Self- } \\
\text { empl. }\end{array}$ & $\begin{array}{l}\text { Sales } \\
\text { assets }\end{array}$ & Transfers & Total \\
\hline $\begin{array}{l}\text { Gini coeff. } \\
\left(G_{i} \text { and } G\right)\end{array}$ & 0.63 & 0.52 & 0.84 & 0.90 & 0.90 & 0.83 & 0.49 \\
\hline Share in $G$ & 0.28 & 0.25 & 0.13 & 0.16 & 0.06 & 0.12 & 1.00 \\
\hline $\begin{array}{l}\text { Concentration } \\
\text { ratio }\left(C_{i}\right)\end{array}$ & 0.46 & 0.40 & 0.53 & 0.66 & 0.63 & 0.58 & ----- \\
\hline $\begin{array}{l}\text { Mean income } \\
\text { from source i } \\
\text { (MK/person) }\end{array}$ & 1,105 & 1,104 & 425 & 436 & 160 & 377 & 3,607 \\
\hline $\begin{array}{l}\text { Share in total } \\
\text { income }\left(\mathrm{w}_{\mathrm{i}}\right)\end{array}$ & 0.31 & 0.31 & 0.12 & 0.12 & 0.04 & 0.10 & 1.00 \\
\hline $\mathrm{w}_{\mathrm{i}} \mathrm{C}_{\mathrm{i}}$ & 0.14 & 0.12 & 0.06 & 0.08 & 0.03 & 0.06 & 0.49 \\
\hline
\end{tabular}


Table 4. Participation rates and earnings shares by forest activity, sample households 1999/2000

\begin{tabular}{|c|c|c|c|c|c|c|c|c|}
\hline & \multicolumn{4}{|c|}{ Participation rate $(\%)$} & \multicolumn{4}{|c|}{ Earnings share (\%) } \\
\hline & Village 1 & Village 2 & Village 3 & All & Village 1 & Village 2 & Village 3 & All \\
\hline Low-return activities (LRFA) & 74 & 71 & 64 & 71 & 22 & 16 & 20 & 19 \\
\hline Sales of crafts ${ }^{a}$ & 13 & 34 & 5 & 19 & 2 & 5 & 0 & 3 \\
\hline Roof thatching and brick burning & 18 & 13 & 9 & 14 & 3 & 2 & 0 & 2 \\
\hline Sales of food and drink ${ }^{b}$ & 59 & 26 & 23 & 38 & 12 & 2 & 5 & 6 \\
\hline Sales of firewood/bamboo & 13 & 21 & 45 & 23 & 2 & 4 & 15 & 6 \\
\hline Traditional medicine & 5 & 8 & 5 & 6 & 3 & 2 & 0 & 2 \\
\hline High-return activities (HRFA) & 38 & 5 & 36 & 25 & 15 & 4 & 21 & 12 \\
\hline Forest employment $^{c}$ & 36 & 0 & 0 & 14 & 13 & 0 & 0 & 5 \\
\hline Charcoal sales $^{\mathrm{d}}$ & 0 & 0 & 36 & 8 & 0 & 0 & 21 & 5 \\
\hline Timber sales ${ }^{\mathrm{e}}$ & 5 & 5 & 0 & 4 & 2 & 4 & 0 & 2 \\
\hline
\end{tabular}

a. Forest-based crafts found at the study sites are: bamboo baskets and mats, grass brooms, and wood-fired pots.

b. Items that use wood as a key input: masese traditional beer, kachasu dry spirit, chikondamoyo cakes, cooked beans, etc.

c. Pit sawing of planks and manual transport of planks from the pit sawing sites on Mulanje Mountain down to the roadside.

d. Sales of own-produced charcoal as well as charcoal resale.

e. Marketing of planks from the forest and trees from private landholdings. 
Table 5. Correlation between forest income share and selected welfare indicators, sample households 1999/2000

\begin{tabular}{|c|c|c|c|}
\hline \multirow[t]{2}{*}{ Variable } & \multicolumn{2}{|c|}{ Forest activities } & \multirow{2}{*}{$\begin{array}{l}\text { Permanent } \\
\text { wage-work }\end{array}$} \\
\hline & LRFA & HRFA & \\
\hline \multicolumn{4}{|l|}{ Income } \\
\hline $\begin{array}{l}\text { Earnings } \\
\text { (Sept. } 2000 \mathrm{MK} / \text { year) }\end{array}$ & $*-0.231$ & * 0.385 & * 0.287 \\
\hline $\begin{array}{l}\text { Total income } \\
\text { (Sept. } 2000 \mathrm{MK} / \text { year) }\end{array}$ & $*-0.231$ & * 0.346 & $* 0.257$ \\
\hline $\begin{array}{l}\text { Per capita earnings } \\
\text { (Sept. } 2000 \mathrm{MK} / \text { person/year) }\end{array}$ & $*-0.203$ & * 0.239 & * 0.199 \\
\hline $\begin{array}{l}\text { Per capita total income } \\
\text { (Sept. } 2000 \mathrm{MK} / \text { person/year) }\end{array}$ & * -0.194 & * 0.194 & 0.173 \\
\hline $\begin{array}{l}\text { Meal consumption } \\
\text { (meals/person/day) }\end{array}$ & -0.019 & 0.162 & 0.176 \\
\hline Number of observations & 99 & 99 & 99 \\
\hline
\end{tabular}

* indicates statistical significance at the 0.05 probability level. 
Table 6. Tobit results for the forest dependence equations

\begin{tabular}{|c|c|c|}
\hline \multirow[t]{2}{*}{ Variable } & \multicolumn{2}{|c|}{ Share of earnings from forest activities } \\
\hline & Model 1 (LRFA) ${ }^{a}$ & Model 2 (HRFA) ${ }^{a}$ \\
\hline Constant & $\begin{array}{r}0.242 \\
(3.154)\end{array}$ & $\begin{array}{r}-0.407 \\
(-1.662)\end{array}$ \\
\hline $\begin{array}{l}\text { Natural log of the ratio of forest returns } \\
(\mathrm{MK} / \mathrm{hour}) \text { and maize returns }(\mathrm{MK} / \mathrm{kg})^{\mathrm{b}}\end{array}$ & $\begin{array}{r}0.042 \\
(2.460)\end{array}$ & $\begin{array}{r}0.398 \\
(5.276)\end{array}$ \\
\hline Farm size per capita (ha/person) & $\begin{array}{r}-0.097 \\
(-1.707)\end{array}$ & $\begin{array}{r}-0.202 \\
(-0.805)\end{array}$ \\
\hline Number of men in the household & $\begin{array}{r}0.012 \\
(0.311)\end{array}$ & $\begin{array}{r}0.513 \\
(4.534)\end{array}$ \\
\hline Number of goats owned & $\begin{array}{r}-0.040 \\
(-2.873)\end{array}$ & $\begin{array}{r}-0.081 \\
(-2.712)\end{array}$ \\
\hline $\begin{array}{l}\text { Household head less than } 35 \text { years of age } \\
(0=\text { No, } 1=\text { Yes })\end{array}$ & $\begin{array}{r}0.008 \\
(0.180)\end{array}$ & $\begin{array}{r}-0.122 \\
(-0.721)\end{array}$ \\
\hline $\begin{array}{l}\text { Household head aged } 35 \text { to } 44 \text { years } \\
(0=\text { No, } 1=\text { Yes })\end{array}$ & $\begin{array}{r}-0.104 \\
(-1.882)\end{array}$ & $\begin{array}{r}0.171 \\
(1.003)\end{array}$ \\
\hline $\begin{array}{l}\text { Household head attended secondary } \\
\text { school }(0=\text { No, } 1=\text { Yes })\end{array}$ & $\begin{array}{r}-0.106 \\
(-1.929)\end{array}$ & $\begin{array}{r}-0.415 \\
(-1.946)\end{array}$ \\
\hline Village 1 residence $(0=$ No, $1=$ Yes $)$ & $\begin{array}{r}0.016 \\
(0.368)\end{array}$ & $\begin{array}{r}0.386 \\
(2.240)\end{array}$ \\
\hline Village 3 residence $(0=$ No, $1=$ Yes $)$ & $\begin{array}{r}0.050 \\
(1.045)\end{array}$ & $\begin{array}{r}0.485 \\
(2.754)\end{array}$ \\
\hline Number of observations & 99 & 99 \\
\hline Log likelihood & -15.64 & -17.27 \\
\hline
\end{tabular}

a. Parenthetical terms are t-statistics.

b. Includes imputed values for missing observations. Details are provided in Fisher (2002) and available upon request. 
Figure 1. Lorenz curves for household income with and without forest income, sample households 1999/2000

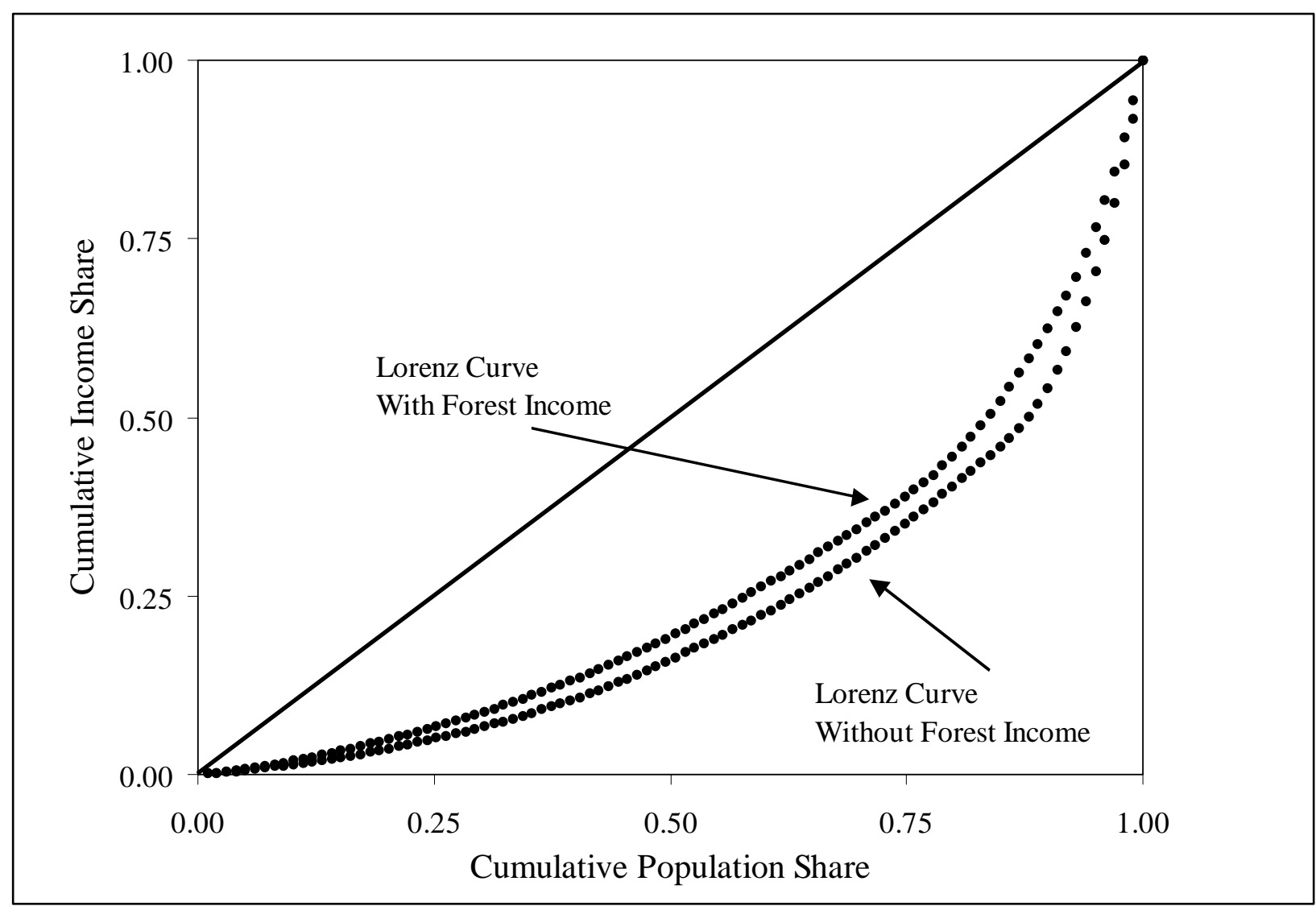




\section{Acknowledgments}

I thank Duncan Chikwita, Busiso Chilambo, G.T.N. Kathindwa, R.J. Kaphesi, the late S.A.R. Mjathu, and colleagues at the Likhubula Forestry Office and University of Malawi’s Centre for Social Research for excellent advice and research assistance during fieldwork in Malawi. Special thanks are due to the respondents who generously participated in the household survey. I thank Gerald Shively and three anonymous reviewers for very useful comments on an earlier version of the paper. This research was supported by a Fulbright grant. 